DOI https://doi.org/10.18551/rjoas.2017-05.16

\title{
THE ROLE OF THE BUREAU OF LOGISTICS (BULOG) IN THE ADEQUACY OF RICE IN BENGKULU PROVINCE, INDONESIA
}

\author{
Efrita E. \\ Faculty of Agriculture, Muhammadiyah University of Bengkulu, Indonesia
}

Sjarkowi F.*, Yazid M., Adriani D.

Faculty of Agriculture, University of Sriwijaya, Indonesia

*E-mail: fachrurrozie sjarkowi@yahoo.co.id

\begin{abstract}
The availability of rice from domestic production is not stable. The role of the Bureau of Logistics (BULOG) is to stabilize the availability of rice by buying the rice at the time of abundant production and distribute it at the time of scarcity. The objective of this study is to analyze the sufficiency of rice in Bengkulu Province based on the availability of rice from the domestic production and the changes in the stock of BULOG of the Regional Division of Bengkulu. The data used are the monthly time series data of the period from 2010 to 2015 . The adequacy of rice is observed at the level of regency/municipality in four categories of adequacy. The results of the calculation on the basis of annual supply and consumption show that Bengkulu Province is in the surplus of rice or in the safe category. The rice sufficiency in all regencies of Bengkulu are also in the safe category, except in the City of Bengkulu that experiences deficit with a category of severe. The rice deficit is most prevalent in December. The provision of rice from BULOG does not have much effect on the sufficiency of rice in Bengkulu Province. BULOG should be aware of rice deficit in Bengkulu City and Lebong Regency especially in the months of January, June and December since in these months centers of rice production also experience rice deficit.
\end{abstract}

\section{KEY WORDS}

Adequacy, availability, rice, production.

Rice is the main staple food in Indonesia. As the nation's main staple food, rice becomes a national strategic commodity. Rice is not only an economic commodity, but also a political commodity that has a broad social dimension. The ever increasing growth of population and the declining of paddy field areas because of the land conversion cause the task of fulfilling rice for the population of Indonesia at every moment and in every region become increasingly more and more difficult.

The supply of rice in Indonesia comes from the domestic production and import. The domestic rice production is unstable since it is influenced by many factors, such as land, technology, climate, and farmers. The provision of rice through importing will have an impact on rice self-sufficiency, food independence and food sovereignty. According to Sjarkowi (2015), food sovereignty is far more important than food security, which means that in fulfilling food sufficiency we should be independent, be technologically oriented, and not be dictated by other countries, and be sustainable. Therefore, the rice supply from the domestic production should receive the most attention from the government.

The Public Enterprise of Bureau Of Logistics (BULOG) is an agency appointed by the government to maintain the stability of the domestic rice. BULOG purchases grain/rice of the domestic production which refers to the Government Purchase Price (GPP) for the Government Rice Reserve (GRR) and rice stocks for subsidized rice program for low-income communities. The rice is then distributed to the poor and the food-insecure population, in a state of emergency or disaster, in a state of social conflict, and at a time when rice prices are uncontrollable. The stock changes of BULOG indicates the provision of rice by the government. If the change is positive, the government's rice reserve increases and the 
supply of rice for the public is reduced. If it is negative, the government's rice reserve decreases and the provision of rice for the people increases.

Based on the Map of Food Resilience and Food Vulnerability (Food Security Council, 2015), Bengkulu Province is in the category of high surplus of rice, in which the ratio of per capita normative consumption to the net production of cereals (rice, maize, cassava and sweet potato) is less than 0.5 . However, the circumstance of this surplus of rice sufficiency is questionable. The question is whether the production is overestimate or the demand is underestimate. In Bengkulu Province, much rice is found from the neighboring provinces, such as Lampung, South Sumatra, West Sumatra, even from outside the island of Sumatra, such as Banten and West Java, as well as imported rice in BULOG of the Regional Division of Bengkulu. Therefore, the writer is interested in doing a more in-depth analysis of the role of BULOG of the Regional Division of Bengkulu in stabilizing the availability and the sufficiency of rice in Bengkulu Province.

\section{METHODS OF RESEARCH}

Time and Location of the Study. This study was conducted from January 2014 to November 2016 in the Province of Bengkulu. Bengkulu was selected as the study area since the contribution of the sub-sector of the agriculture to the GDP is still fairly high at 31 percent and rice is the staple food of the population. Additionally, in the Province of Bengkulu there is one city that always experiences a deficit in rice, which is surrounded by 9 regencies which are in surplus of rice.

Types and Sources of Data. The data used in this study are monthly time series data of the period from 2010 to 2015 . The variables used are the size of population, per capita consumption of rice, domestic rice production, and changes in stocks of rice of BULOG of the Regional Division of Bengkulu.

Analytical Model. The analytical method used is the descriptive qualitative analysis. The facts, the phenomena, the variables, and the circumstances that occur at the time of study are described as they are and are presented in the form of tables, graphs, or figures.

Rice sufficiency is viewed in terms of the supply (availability of rice) and in terms of the demand (consumption of rice). Rice sufficiency means that there is a balance between the availability of rice with the amount of rice consumption. If the amount of the availability exceeds the amount of consumption, it means a surplus occurs, and vice versa, if the amount of the availability is less than the amount of consumption, a deficit of rice occurs. The rice sufficiency is stated as follows:

$$
\begin{aligned}
& C B=Q S B-Q K B \\
& C B>0=\text { Surplus of rice (ton) } \\
& C B<0=\text { Deficit ofrice (ton) }
\end{aligned}
$$

Where: $\mathrm{CB}=$ Rice sufficiency (ton); $\mathrm{QSB}=$ Total availability of rice (ton); $\mathrm{QKB}=$ Total consumption of rice (ton).

To reveal the role of the Bureau Of Logistics (BULOG) of Regional Division of Bengkulu in the sufficiency of rice in Bengkulu Province, the availability of rice is calculated by two approaches. The first approach is to calculate the availability of rice from the domestic production without role of $B U L O G$. The rice availability with the first approach is calculated by using the equation:

$$
Q S B_{1}=0,6274(Q P G-Q G P a-Q G C)-(Q B P a+Q B C)
$$

Where: $\mathrm{QSB}_{1}=$ Total availability of rice from the domestic production without the role of $B U L O G$ (ton); 0,6274= Conversion rate of dry milled grain into rice; $Q P G=$ Total grain production (ton); $\mathrm{QGPa}=$ The amount of grain used for feed (ton); $\mathrm{QGC}=$ Number of grain spilled (ton); QBPa = The amount of rice used for feed (ton); QBC = The amount of scattered rice (ton). 
The second approach is to calculate the availability of rice from the domestic production with role of $B U L O G$. The availability of rice with this second approach is calculated by using the equation:

$$
Q S B_{2}=[0,6274(Q P G-Q G P a-Q G C)-Q \triangle S B P]-(Q B P a+Q B C)
$$

Where: $\mathrm{QSB}_{2}=$ Total availability of rice from the domestic production with role of $B U L O G$ (ton); $\mathrm{Q} \triangle \mathrm{SBP}=$ The role of $B U L O G$, proxied by variable changing the rice stok of $B U L O G$ (ton).

The grain used for feed and that which is scattered is respectively $0.44 \%$ and $5.4 \%$ of the supply of grain, while the rice used for feed and that which is scattered is respectively $0.17 \%$ and $2.5 \%$ of the supply of rice (Food Security Agency of Bengkulu Province, 2015). This percentage is used to proxy the availability of rice.

The consumption of a commodity is affected by the price of the commodity itself, the prices other commodities, both the substitutes and the complements, the level of income, the tastes or preferences of consumers, and the population, and other shift factors. For the commodity of rice which is the staple food of Indonesia's population, the factor of the increasing population is the major factor that causes rice consumption to continue growing from year to year.

In addition to household consumption, rice is also used for food processing industry and the needs of hotels and restaurants (Erwidodo and Pribadi, 2003). In this study the reseacher restricted the analysis of rice only for household consumption. The amount of rice consumption of the residents of Bengkulu Province is obtained by multiplying the per capita consumption of rice by the size of population, by using the following equation:

$$
Q K B=a J P
$$

Where: $\mathrm{QKB}=$ Total consumption of rice; $\mathrm{a}=$ Amount of rice consumption per capita; $\mathrm{JP}=$ size of population.

By substituting equation (2) and (4) into the equation (1), the rice sufficiency equation is obtained as follows:

$$
C B_{1}=[0,6274(Q P G-Q G P a-Q G C)-(Q B P a+Q B C)]-a J P
$$

And by substituting equation (3) and (4) into the equation (1), the rice sufficiency equation is obtained as follows:

$$
C B_{2}=\{[0,6274(Q P G-Q G P a-Q G C)-Q \Delta S B P]-(Q B P a+Q B C)\}-a J P
$$

Per capita rice consumption is obtained through three approaches, namely the actual consumption, the normative consumption, and the consumption of food-insecure households. The actual consumption is obtained from the information issued by the Provincial Food Security Agency of Bengkulu. The normative consumption is obtained from the Regulation of the Ministry of Health of the Republic of Indonesia Number 75 of 2013 about The Nutrition Adequacy Score that is recommended for Indonesian People, namely as much as 2,150 $\mathrm{kcal} / \mathrm{capita} /$ day on the consumption levels. Based on the National Desirable Dietary Pattern (NDDP), 50 percent of the energy needs is fulfilled by consuming food of grains group. While the rice consumption in food-insecure households is obtained from the energy consumption of food-insecure households according to Jonsson and Tole in Maxwell et al., (2000), that is $<860 \mathrm{kcal} /$ capita/day.

Rice sufficiency in Bengkulu Province is divided into four categories, namely:

1. Safe, that is the condition when the amount of the rice availability is more than the amount of the actual consumption, which means that there is a surplus of rice (CB > $0)$. This area is colored purple. 
2. Healthy, that is the condition when the amount of the rice availability is less than the actual amount of rice consumption, but larger than the normative consumption, which means that a deficit in rice occurs $(C B<0)$. This area is colored green.

3. Crisis, that is the condition when the amount of the rice availability is less than the amount of rice for normative consumption, but larger than the consumption of rice in food-insecure households, which means that a deficit in rice occurs $(C B<0)$. This area is highlighted in yellow.

4. Severe, that is the condition when the amount of the rice availability is less than the amount of rice for the consumption of insecure households, which means that a deficit in rice occurs $(C B<0)$. This area is colored red.

The sufficiency in rice can be explained in Figure 1.

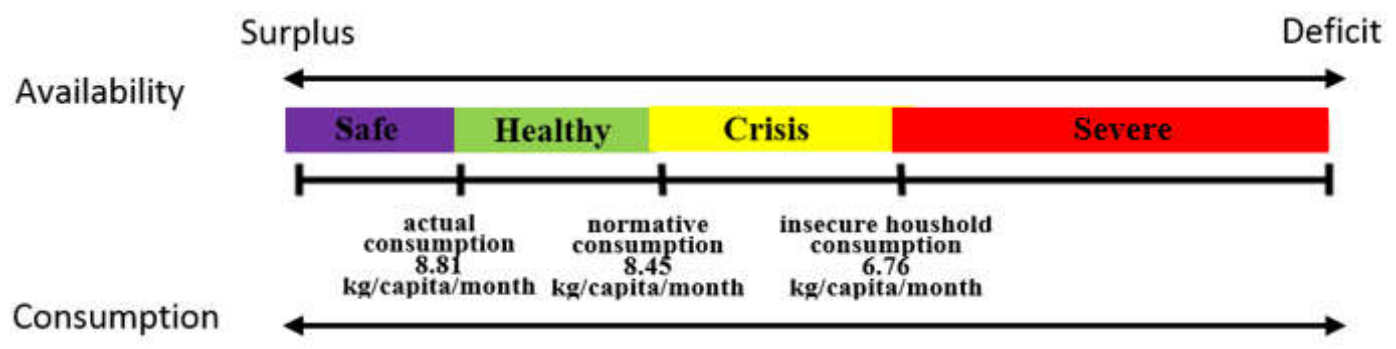

Figure 1 - The Categories of Rice Sufficiency in the Province of Bengkulu

\section{RESULTS AND DISCUSSION}

Bengkulu Province is located in the western side of the Bukit Barisan Mountains and is directly adjacent to the Indian Ocean with a coastline of approximately 525 kilometers. The astronomical location of Bengkulu Province is between latitudes $2^{\circ} 16^{\prime} S$ to $3^{\circ} 31^{\prime} S$ and between longitudes $101^{\circ} 01^{\prime} \mathrm{E}$ to $103^{\circ} 41^{\prime} \mathrm{E}$. The existing area, $1,724,103$ hectares $(86.55$ percent) as agricultural land, consisting of 1,632,452 hectares of agricultural land other than paddy fields and 91,651 hectares of paddy fields. Paddy is the food crops that is dominantly cultivated in the Province of Bengkulu, consists of 93.46 percent wetland paddy and 6.54 dryland paddy (BPS-Statistics of Bengkulu Province, 2016).

The type of climate of Bengkulu Province is categorized as type A according to Schmidt's and Ferguson's climate classification, allowing rice farming throughout the year because the availability of water is ensured. The season that occurred in the Province of Bengkulu are two seasons: the rainy season which occurs in the month of December to March and the dry season which occurs in the month of June to September. While in AprilMay and October-November is a transition.

The availability of rice comes from the domestic production and the changes in the stock of BULOG of Regional Division of Bengkulu. The availability of rice is presented in Table 1.

Table 1 - The availability of rice in the Province of Bengkulu in the period of 2010-2015

\begin{tabular}{cccccc}
\hline & & \multicolumn{3}{c}{ Rice Availability (ton) } & Growth \\
\cline { 3 - 5 } No. & Years & domestic production & $\begin{array}{c}\text { changes in stock } \\
\text { of BULOG }\end{array}$ & $(4)$ & $(5=3-4)$ \\
\hline$(1)$ & $(2)$ & $(3)$ & $4,468.94$ & $292,601,77$ & - \\
\hline 1. & 2010 & $297,193.30$ & $-6,228.50$ & $295,358,78$ & 0,94 \\
2. & 2011 & $288,959.42$ & $5,664.88$ & $328,771,29$ & 11,31 \\
3. & 2012 & $334,591.57$ & $-5,877.34$ & $364,160,32$ & 10,76 \\
4. & 2013 & $358,121.75$ & $1,673.83$ & $339,358,25$ & $-6,81$ \\
5. & 2014 & $341,078.00$ & 953.69 & $331,738,42$ & $-2,25$ \\
\hline 6 & 2015 & $332,718.27$ & & & \\
\hline
\end{tabular}

The data in Table 1 show that the availability of rice until 2013 increased $7.67 \%$ per year, but in the period of 2014 to 2015 the availability of rice declined $4.53 \%$ per year. 
Rice consumption of the population of Bengkulu Province is still high. In 2015, the consumption of food of grains group reached 67.3 percent of the Nutritional Adequacy Score (Food Security Agency of Bengkulu Province, 2016). The development of consumption of food of grains group by the population of Bengkulu Province can be seen in Table 2.

Table 2 - The Consumption of the Food of the Grain Group by the Residents of Bengkulu Province in the Period of 2010-2015

\begin{tabular}{cccccc}
\hline No. & Years & $\begin{array}{c}\text { Grain } \\
\text { (kg/capita) }\end{array}$ & $\begin{array}{c}\text { Rice } \\
\text { (kg/capita) }\end{array}$ & Corn (kg/capita) & Wheat (kg/capita) \\
\hline 1. & 2010 & 128.30 & 119.60 & 0.30 & 8.40 \\
2. & 2011 & 121.50 & 111.80 & 0.70 & 9.00 \\
3. & 2012 & 114.70 & 106.30 & 0.40 & 8.00 \\
4. & 2013 & 114.80 & 106.40 & 0.20 & 7.50 \\
5. & 2014 & 113.59 & 105.69 & 0.40 & 12.50 \\
6. & 2015 & 119.33 & 106.13 & 0.70 & 8.93 \\
\hline \multicolumn{2}{l}{ Average (kg/capita) } & 118.70 & 109.32 & 0.45 & 6.70 \\
\hline \multicolumn{2}{l}{ Standard (kg/capita) } & 100.40 & 91.00 & 2.70 & 11.33 \\
\hline
\end{tabular}

The data in Table 2 show that the consumption of rice per capita by the population of Bengkulu Province is the highest as compared to the consumption of corn and wheat. This is consistent with the results of the study by Cahyani (2008) and Lantarsih et al. (2011) which indicates that rice is still the main energy source in Indonesia compared to any other food of grain group.

The data in Table 2 also indicate that per capita rice consumption tends to decline due to rising income of the people. The GRDP of Bengkulu Province based on the valid prices of 2010 was 18.60 trillion. In 2015 the GRDP at constant prices of 2010 increased to 38.07 trillion. According to Engel's Law, at the time of low income, most of the budget is spent on the staple food need. When income increases, the proportion of income spent on buying the staple food is reduced, although the actual expenditures for food increased (Chai and Moneta, 2010).

The rising income of the people lead to the shifting of rice consumption to other foods made of flour, such as instant noodles and bread. This is indicated by the increase of per capita flour consumption by $8.4 \mathrm{~kg}$ per capita in 2010 to $12.5 \mathrm{~kg}$ per capita in 2015 . Wheat is an imported foodstuff, the increase of its consumption will thresten the food independence and food sovereignty.

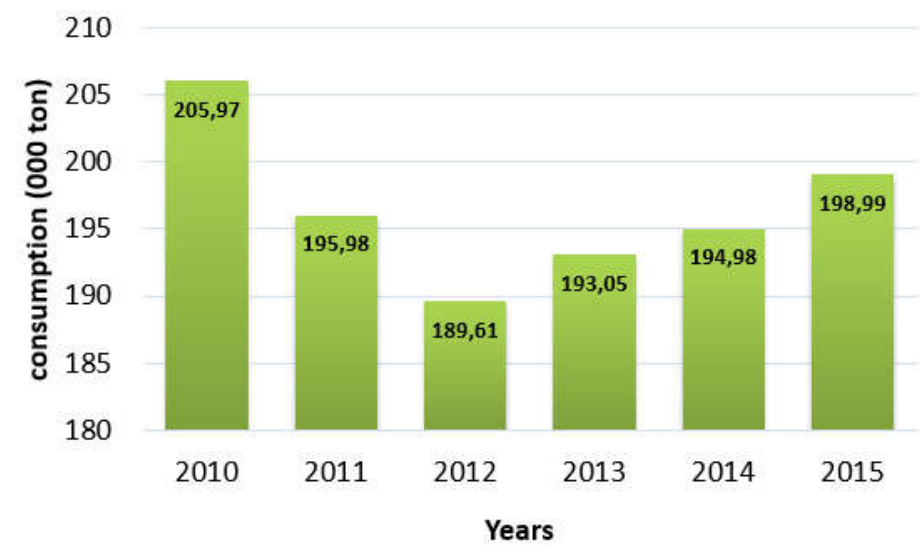

Figure 2 - Total Rice Consumption in Bengkulu Province, 2010-2015

The increasing knowledge about health and nutrition causes the decrease of rice consumption. The results of the study by Park et al. (2005) showed that the pattern of food was very closely related to education and health behaviors. According to Hu (2002), the 
increase of disease risk is caused by errors of food consumption patterns, such as excessive consumption of rice can trigger diabetes.

Rice consumption decreases due to the successful implementation food diversification program. The consumption of tubers increased from $27.4 \mathrm{~g} /$ capita/ day in 2014 to 33.8 g/capita/day in 2015. In addition, the decline in rice consumption may also be due to saving behavior in consuming rice. The results of the study by Anriany and Martianto (2013) wasteful practices can cause a loss of 4.7 grams of rice per capita per day, an equivalent of $1.72 \mathrm{~kg}$ per capita per year. Total rice consumption in Bengkulu Province for 2010 - 2015 period can be seen in Figure 2.

The data in Figure 2 show that the greatest amount of rice consumption occurred in 2010. This is due to the fact that the consumption of rice per capita in 2010 was still very high (119.6 kg per capita). In the period of 2011 - 2012 the consumption of rice decreased with decreasing per capita consumption of rice. Later in the period of 2013 - 2015 per capita rice consumption was declining, however because the population continued increasing, the amount of rice consumption began to rise again from year to year. The results of this study are consistent with the results of the study by Efrita (2001) which show that the projected demand for rice increases annually in Bengkulu Province. Nur et al. (2012) suggested that the elasticity of the population against rice consumption was much higher than the elasticity of the price of rice, the price of wheat, the rice production and the income.

The results of the calculation of rice adequacy are presented in Table 3.

Table 3 - Rice sufficiency in Bengkulu Province, 2010-2015

\begin{tabular}{|c|c|c|c|c|c|}
\hline \multirow[b]{2}{*}{ No. } & \multirow[b]{2}{*}{ Years } & \multicolumn{2}{|c|}{ Sufficiency (kg) } & \multicolumn{2}{|c|}{ Sufficiency ahead (Months) } \\
\hline & & $\begin{array}{c}\text { without the role } \\
\text { of } B U L O G\end{array}$ & $\begin{array}{l}\text { with the role } \\
\text { of } B U L O G\end{array}$ & $\begin{array}{c}\text { without the role } \\
\text { of } B U L O G\end{array}$ & $\begin{array}{c}\text { with the role } \\
\text { of } B U L O G\end{array}$ \\
\hline 1. & 2010 & $91,226.79$ & $86,635.26$ & 5.32 & 5.05 \\
\hline 2. & 2011 & $92,978.94$ & $99,378.30$ & 5.69 & 6.08 \\
\hline 3. & 2012 & $144,981.61$ & $139,161.33$ & 9.18 & 8.81 \\
\hline 4. & 2013 & $165,074.16$ & $171,112.74$ & 10.26 & 10.64 \\
\hline 5. & 2014 & $146,102.35$ & $144,382.60$ & 8.99 & 8.89 \\
\hline 6. & 2015 & $133,730.46$ & $132,750.61$ & 8.06 & 8.01 \\
\hline
\end{tabular}

The data in Tabel 3 indicate that the rice sufficiency in Bengkulu Province is in the safe category. The rice availability from the domestic rice production and the changes in the stock of BULOG can meet the needs of the population of Bengkulu Province with safe category. The surplus of rice in Bengkulu Province can meet the needs of rice for 5 to 10 months ahead. This is consistent with the Map of Food Resilience and Food Vulnerability (Food Security Council, 2015) which states that Bengkulu Province is in the category of high surplus. These findings refute the statement of Romdhon (2013) which states that Bengkulu Province experiences a deficit in rice, in which domestic rice production meets only 30.39 percent of the need of rice.

The results of the calculation of rice adequacy in the regencies / the municipalities of the availability from the domestic rice production in Bengkulu Province are presented in Table 4.

Table 4 - Rice Sufficiency in Bengkulu Province by the Regencies/Municipalities, 2010-2015

\begin{tabular}{cccccccc}
\hline \multirow{2}{*}{ No. } & Regency/ & \multicolumn{7}{c}{ Years } \\
\cline { 3 - 7 } & Municipality & 2010 & 2011 & 2012 & 2013 & 2014 & 2015 \\
\hline 1. & Bengkulu South & 19,659 & 22,077 & 29,492 & 25,146 & 34,858 & 34,900 \\
2. & Rejang Lebong & 11,408 & 14,284 & 20,143 & 30,317 & 27,002 & 21,800 \\
3. & North Bengkulu & 18,274 & 14,411 & 24,884 & 22,533 & 31,674 & 11,875 \\
4. & Kaur & 9,558 & 5,928 & 17,285 & 16,706 & 11,269 & 17,619 \\
5. & Seluma & 25,118 & 19,029 & 29,970 & 28,856 & 17,090 & 14,493 \\
6. & Mukomuko & 4,041 & 14,074 & 8,061 & 23,029 & 11,961 & 28,209 \\
7. & Lebong & 18,637 & 15,459 & 18,183 & 17,010 & 15,371 & 18,018 \\
8. & Kepahiang & 3,964 & 9,274 & 13,886 & 17,157 & 16,197 & 13,396 \\
9. & Central Bengkulu & 11,236 & 8,170 & 10,880 & 9,188 & 8,752 & 6,744 \\
10. & Bengkulu City & $-30,668$ & $-29,726$ & $-27,802$ & $-24,868$ & $-28,071$ & $-33,323$ \\
\hline
\end{tabular}


The data in Table 4 show that nine regencies in Bengkulu Province are in surplus of rice in which the availability of per capita is higher than the actual per capita consumption, therefore the sufficiecy of rice is in the category of safe and is given a purple color. The only area that experiences a deficit in rice in Bengkulu Province is the City of Bengkulu. The availability of rice from the domestic rice production in Bengkulu City is only 11-32 kg per capita, far below the consumption of food-insecure households in the amount of $80.30 \mathrm{~kg}$ per capita. Therefore, the rice sufficiency of Bengkulu City is categorized as severe and is colored red.

An analysis of monthly rice sufficiency is performed to see if the supply of rice from the domestic rice production and the changes in the stock of BULOG of the Regional Division of Bengkulu can meet the needs of rice consumption of the population of Bengkulu Province every month. The monthly availability of rice from the domestic rice production and the changes in the stock of BULOG are presented in Table 5.

Table 5 - The Monthly Rice Availability in Bengkulu Province, 2010-2015 (Ton)

\begin{tabular}{|c|c|c|c|c|c|c|c|c|c|c|c|c|c|c|c|}
\hline \multirow{2}{*}{ No. } & \multirow{2}{*}{ Years } & \multirow{2}{*}{ Availability } & \multicolumn{12}{|c|}{ Months } & \multirow{2}{*}{ Averages } \\
\hline & & & Jan & Feb & Mar & Apr & May & Jun & Jul & Aug & Sep & Oct & Nov & Dec & \\
\hline \multirow[t]{3}{*}{1.} & 2010 & Production & 23,141 & 21,377 & 37,536 & 27,161 & 18,362 & 19,431 & 24,111 & 31,289 & 18,462 & 17,431 & 26,032 & 32,860 & 24,766 \\
\hline & & BULOG stock & 423 & 1,026 & -600 & 17 & 1,560 & 450 & -864 & $-2,481$ & 601 & $-1,646$ & $-2,321$ & -633 & -372 \\
\hline & & Total & 22,718 & 20,351 & 38,136 & 27,144 & 16,802 & 18,981 & 24,975 & 33,770 & 17,862 & 19,077 & 28,353 & 33,493 & 25,139 \\
\hline \multirow[t]{3}{*}{2.} & 2011 & Production & 15,964 & 20,517 & 30,298 & 42,465 & 21,916 & 33,297 & 23,479 & 16,894 & 24,659 & 20,560 & 28,366 & 10,544 & 24,080 \\
\hline & & BULOG stock & 3233 & $-1,240$ & -540 & 2,617 & 5,228 & -97 & $-1,027$ & $-2,315$ & $-1,558$ & 1,438 & -511 & 1,000 & 519 \\
\hline & & Total & 12,731 & 21,757 & 30,838 & 39,848 & 16,689 & 33,394 & 24,505 & 19,209 & 26,217 & 19,121 & 28,877 & 9,545 & 23,561 \\
\hline \multirow[t]{3}{*}{3.} & 2012 & Production & 17,622 & 28,491 & 54,528 & 43,308 & 28,362 & 23,633 & 26,171 & 28,866 & 20,757 & 21,664 & 25,159 & 16,032 & 27,883 \\
\hline & & BULOG stock & 592 & 1,235 & -740 & $-2,466$ & 1,470 & -246 & 90 & -392 & $-3,223$ & 2,633 & $-2,201$ & $-2,416$ & -472 \\
\hline & & Total & 17,030 & 27,256 & 55,268 & 45,774 & 26,892 & 23,878 & 26,080 & 29,258 & 23,980 & 19,031 & 27,360 & 18,447 & 28,355 \\
\hline \multirow[t]{3}{*}{4.} & 2013 & Production & 21,769 & 29,014 & 68,086 & 43,487 & 29,219 & 24,270 & 24,624 & 19,120 & 27,764 & 35,043 & 21,458 & 14,268 & 29,844 \\
\hline & & BULOG stock & 4,889 & 604 & $-1,843$ & $-3,063$ & 4,753 & -265 & $-1,163$ & 1,676 & -666 & $-1,021$ & -600 & 2,575 & 490 \\
\hline & & Total & 16,880 & 28,410 & 69,929 & 46,550 & 24,466 & 24,535 & 25,787 & 17,444 & 28,430 & 36,064 & 22,058 & 11,693 & 29,354 \\
\hline \multirow[t]{3}{*}{5.} & 2014 & Production & 19,627 & 35,690 & 62,221 & 28,011 & 17,582 & 29,669 & 23,655 & 19,351 & 38,245 & 35,285 & 19,234 & 12,507 & 28,423 \\
\hline & & BULOG stock & 2,770 & -354 & $-3,299$ & 2,040 & -20 & $-3,002$ & -551 & -606 & $-1,525$ & 4,146 & -227 & $-1,047$ & -140 \\
\hline & & Total & 16,857 & 36,044 & 65,520 & 25,971 & 17,602 & 32,671 & 24,205 & 19,957 & 39,770 & 31,139 & 19,461 & 13,555 & 28,563 \\
\hline \multirow[t]{3}{*}{6.} & 2015 & Production & 16,551 & 27,378 & 56,745 & 40,810 & 28,910 & 23,172 & 12,464 & 20,557 & 45,707 & 27,632 & 20,701 & 12,090 & 27,726 \\
\hline & & BULOG stock & $-1,655$ & 265 & $-2,661$ & 882 & 3,407 & -209 & -8 & 499 & -196 & $-1,269$ & $-3,254$ & 3,244 & -80 \\
\hline & & Total & 18,207 & 27,113 & 59,406 & 39,928 & 25,502 & 23,381 & 12,472 & 20,058 & 45,903 & 28,901 & 23,955 & 8,846 & 27,806 \\
\hline \multirow{3}{*}{\multicolumn{2}{|c|}{ Averages }} & Production & 19,112 & 27,078 & 51,569 & 37,540 & 24,059 & 25,579 & 22,417 & 22,680 & 29,266 & 26,269 & 23,492 & 16,383 & 27,120 \\
\hline & & BULOG stock & 1,709 & 256 & $-1,614$ & 4 & 2,733 & -561 & -587 & -603 & $-1,095$ & 714 & $-1,519$ & 454 & \\
\hline & & Total & 17,404 & 26,822 & 53,183 & 37,536 & 21,326 & 26,140 & 23,004 & 23,283 & 30,360 & 25,555 & 25,011 & 15,930 & 27,130 \\
\hline
\end{tabular}

The data in Table 5 show that the minimum rice availability is 10,544 tonnes of rice which occurred in December 2011 and the maximum is 68,086 tonnes which occurred in March 2013. The average availability is 27,120 tonnes. The provision of rice from the stock of $B U L O G$ of the Regional Division of Bengkulu does not function properly. Supposedly, $B U L O G$ should increase the stock of rice by buying the rice from the farmers during the harvest and release the rice stock at the time of scarcity. In adding and releasing stocks of rice, BULOG did not pay attention to the fluctuations of the availability of the domestic rice as shown in Figure 3.

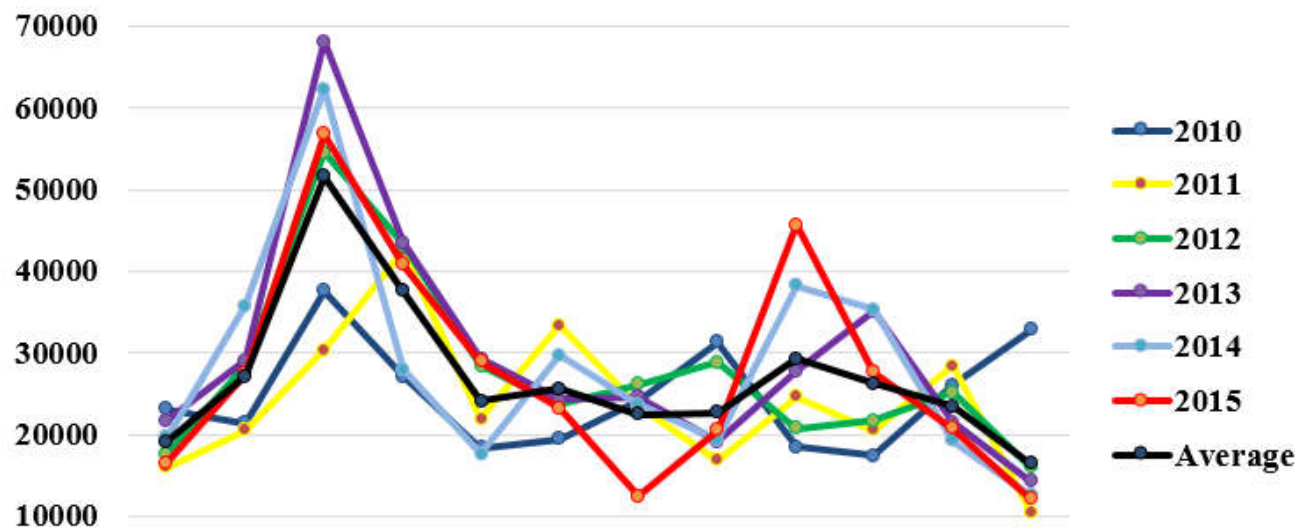

Jan Feb Mar Apr May Jun Jul Aug Sep Oct Nov Dec

Figure 3 - The Monthly Availability of Rice from the Domestic Rice Production in Bengkulu Province, 2010-2015 (ton) 
The data in Figure 3 show that the domestic rice production has a certain pattern, in which during March the production reaches its peak, then it declines and rises again in September. Then the production decreases again and reaches the lowest production in December. Thus, BULOG should increase the stock in March and September and release the stock from November to January. However, the opposite happens, BULOG releases the stock of rice at the harvest time, namely March and increases the stock of rice during the scarcity, namely in December.

Total monthly rice consumption of the population of Bengkulu Province in the period of 2010-2015 are presented in Table 6.

Table 6 - Monthly Rice Consumption in Bengkulu Province, 2010-2015 (ton)

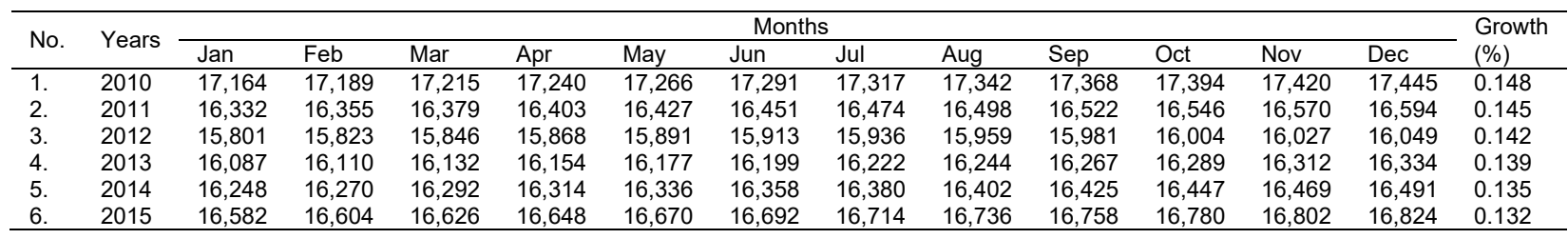

The data in Tabel 6 show that the amount of rice consumption increases each month. The increase of the amount of consumption depends on the amount of rice consumption per capita and the population growth.

The results of the calculation of rice adequacy from the domestic rice production without the role of BULOG are presented in Table 7.

Table 7.Monthly Rice Sufficiency in Bengkulu Province Through the Availability of the Domestic Rice Production Without the Role of BULOG, 2010-2015

\begin{tabular}{|c|c|c|c|c|c|c|c|c|c|c|c|c|c|}
\hline \multirow{2}{*}{ No. } & \multirow{2}{*}{ Years } & \multicolumn{12}{|c|}{ Months } \\
\hline & & Jan & Feb & Mar & Apr & May & Jun & Jul & Aug & Sep & Oct & Nov & Dec \\
\hline 1. & 2010 & 5,977 & 4,188 & 20,321 & 9,921 & 1,097 & 2,140 & 6,794 & 13,946 & 1,094 & 37 & 8,613 & 15,415 \\
\hline 2. & 2011 & -367 & 4,162 & 13,919 & 26,062 & 5,490 & 16,847 & 7,004 & 396 & 8,136 & 4,014 & 11,795 & $-6,050$ \\
\hline 3. & 2012 & 1,821 & 12,668 & 38,682 & 27,439 & 12,471 & 7,720 & 10,235 & 12,908 & 4,776 & 5,660 & 9,132 & -18 \\
\hline 4. & 2013 & 5,682 & 12,905 & 51,954 & 27,332 & 13,043 & 8,071 & 8,402 & 2,876 & 11,497 & 18,754 & 5,146 & $-2,067$ \\
\hline 5. & 2014 & 3,379 & 19,420 & 45,929 & 11,697 & 1,246 & 13,311 & 7,275 & 2,949 & 21,820 & 18,838 & 2,765 & -3.984 \\
\hline 6. & 2015 & -31 & 10,774 & 40,119 & 24,162 & 12,240 & 6,480 & $-4,250$ & 3,821 & 28,949 & 10,852 & 3,899 & $-4,734$ \\
\hline
\end{tabular}

The data in Table 7 show that the frequency of the deficit in the period of 2010 to 2015 is only 8 months, in which 3 months of them are in the healthy category (green), 1 month is in the crisis category (yellow) and 4 months are in the severe category (red). The deficit frequently occurs in December. The most frequent deficits occurred in 2015.

The results of the calculation of rice adequacy originating from the availability of the domestic rice production with the role of BULOG are presented in Table 8.

Table 8 - Monthly Rice Sufficiency in Bengkulu Province Through the Availability of the Domestic Rice Production with the Role of BULOG, 2010-2015

\begin{tabular}{|c|c|c|c|c|c|c|c|c|c|c|c|c|c|}
\hline \multirow{2}{*}{ No. } & \multirow{2}{*}{ Tahun } & \multicolumn{12}{|l|}{ Bulan } \\
\hline & & Jan & Feb & Mar & Apr & May & Jun & Jul & Aug & Sep & Oct & Nov & Dec \\
\hline 1. & 2010 & 5,554 & 3,162 & 20,921 & 9,904 & -464 & 1,690 & 7,658 & 16,428 & 494 & 1,683 & 10,934 & 16,048 \\
\hline 2. & 2011 & $-3,601$ & 5,401 & 14,459 & 23,445 & 262 & 16,943 & 8,031 & 2,710 & 9,695 & 2,575 & 12,307 & $-7,050$ \\
\hline 3. & 2012 & 1,229 & 11,433 & 39,423 & 29,906 & 11,001 & 7,965 & 10,144 & 13,300 & 7,999 & 3,027 & 11,334 & 2,398 \\
\hline 4. & 2013 & 792 & 12,301 & 53,797 & 30,395 & 8,290 & 8,336 & 9,565 & 1,200 & 12,163 & 19,775 & 5,746 & $-4,642$ \\
\hline 5. & 2014 & 609 & 19,774 & 49,228 & 9,657 & 1,266 & 16,313 & 7,825 & 3,554 & 23,345 & 14,692 & 2,992 & $-2,937$ \\
\hline 6. & 2015 & 1,624 & 10,509 & 42,780 & 23,280 & 8,832 & 6,689 & $-4,242$ & 3,323 & 29,145 & 12,121 & 7,153 & $-7,978$ \\
\hline
\end{tabular}

The data in Table 8 reveal that only after the intervention of government, namely through BULOG of the Regional Division of Bengkulu, there are 7 months of deficit frequency, namely 1 month in the healthy category, two months in the crisis category, and 4 months in the severe category.

In terms of quantity, the government intervention caused the frequency of deficits to decrease from 8 to 7 months. But in terms of quality, the government intervention does not significantly affect the sufficiency of rice in the Province of Bengkulu. 
Table 9 - The Monthly Rice Sufficiency of the Population of Bengkulu Province by Regency/Municipality, 2010-2016

\begin{tabular}{|c|c|c|c|c|c|c|c|c|c|c|c|c|c|}
\hline \multirow{2}{*}{ No. } & \multirow{2}{*}{$\begin{array}{l}\text { Regency/ } \\
\text { Municipality }\end{array}$} & \multicolumn{12}{|c|}{ Months } \\
\hline & & Jan & Feb & Mar & Apr & May & Jun & Jul & Aug & Sep & Oct & Nov & Dec \\
\hline \multirow[t]{7}{*}{1.} & South Selatan & & & & & & & & & & & & \\
\hline & 2010 & 2,400 & 1,095 & 6,781 & 2,938 & 283 & -162 & 1,771 & 2,025 & -121 & 102 & 1,923 & 523 \\
\hline & 2011 & $-1,091$ & 928 & 5,847 & 8,551 & 1,063 & -545 & $-1,212$ & $-1,158$ & 2,355 & 1,833 & 5,490 & -77 \\
\hline & 2012 & $-1,177$ & $-1,094$ & 7,405 & 15,032 & 1,287 & $-1,229$ & $-1,179$ & -313 & 1,212 & 7,631 & 2,838 & $-1,007$ \\
\hline & 2013 & $-1,320$ & -154 & 10,820 & 6,126 & 261 & $-1,188$ & -793 & -819 & 4,591 & 4,965 & 2,542 & 30 \\
\hline & 2014 & -416 & 493 & 15,369 & 3,355 & -475 & -744 & $-1,333$ & $-1,191$ & 4,662 & 12,509 & 3,264 & -712 \\
\hline & 2015 & $-1,260$ & 1,039 & 14,700 & 8,411 & $-1,336$ & $-1,023$ & $-1,323$ & -443 & 3,841 & 13,242 & 255 & $-1,286$ \\
\hline \multirow[t]{7}{*}{2.} & Rejang Lebong & & & & & & & & & & & & \\
\hline & 2010 & -414 & -88 & 957 & 446 & 1,195 & 1,939 & 1,254 & 2,080 & 115 & 167 & 1,295 & 2,357 \\
\hline & 2011 & 863 & 137 & 56 & 1,974 & 768 & 610 & -377 & 153 & 3,110 & 2,911 & 2,288 & 1,700 \\
\hline & 2012 & 613 & 2,579 & 1,038 & 785 & 2,567 & 3,768 & 2,028 & 1,211 & 2,553 & 229 & 1,094 & 1,590 \\
\hline & 2013 & 7,991 & 4,630 & 5,230 & 2,550 & 1,507 & -680 & -829 & $-1,562$ & 522 & 6,652 & 4,205 & 24 \\
\hline & 2014 & 1,032 & 5,381 & 5,718 & 3,129 & 1,591 & 918 & -13 & -243 & 1,139 & 2,445 & 3,943 & 1,889 \\
\hline & 2015 & 879 & 3,075 & 5,738 & 3,017 & 1,561 & -457 & 880 & 244 & 3,373 & 1,734 & 1,718 & -30 \\
\hline \multirow[t]{7}{*}{3.} & North Bengkulu & & & & & & & & & & & & \\
\hline & 2010 & 3,989 & 2,018 & 3,148 & 1,613 & 2,494 & 1,492 & 597 & 2,515 & -455 & -473 & 626 & 399 \\
\hline & 2011 & -222 & 2,045 & 5,392 & 4,586 & 1,220 & 604 & 1,609 & 292 & 862 & -596 & -548 & $-1,127$ \\
\hline & 2012 & 2,085 & 4,990 & 2,978 & 2,915 & 2,996 & 1,427 & 1,078 & 410 & 56 & 1,143 & 3,020 & 1,512 \\
\hline & 2013 & 1,646 & 1,805 & 6,035 & 842 & 1,515 & -179 & 2,991 & 3,360 & 1,569 & 1,768 & 131 & 766 \\
\hline & 2014 & 3,612 & 3,398 & 5,152 & 1,342 & 1,392 & 2,298 & 6,860 & 2,466 & 1,709 & 1,399 & 11 & 1,759 \\
\hline & 2015 & 4,056 & 1,181 & 831 & 212 & -179 & 1,824 & -400 & 1,821 & 1,733 & 52 & -1 & 471 \\
\hline 4. & Kaur & & & & & & & & & & & & \\
\hline & 2010 & 1,322 & 1,109 & 2,989 & 2,482 & -834 & -63 & 901 & -69 & -125 & -477 & 1,139 & 1,101 \\
\hline & 2011 & 1,953 & 978 & -63 & 1,024 & -746 & 2,004 & 228 & -347 & 2,244 & $-1,034$ & 258 & -652 \\
\hline & 2012 & -177 & 3,371 & 9,288 & 4,215 & 394 & -908 & -787 & 1,853 & 1,603 & -201 & -780 & -659 \\
\hline & 2013 & 141 & 91 & 9,890 & 4,062 & -368 & $-1,007$ & -844 & 852 & 994 & 1,450 & 1,121 & 252 \\
\hline & 2014 & 1,346 & 3,667 & 2,826 & 1,979 & 670 & -247 & -686 & 239 & 897 & 862 & -199 & -154 \\
\hline & 2015 & 2,871 & 4,901 & 7,902 & 2,136 & 48 & -877 & -465 & 593 & 1,034 & -608 & 800 & -787 \\
\hline 5. & Seluma & & & & & & & & & & & & \\
\hline & 2010 & 2,591 & 3,382 & 4,746 & 2,997 & -39 & -727 & 94 & 2,715 & 1,317 & 413 & 1,222 & 6,279 \\
\hline & 2011 & 1,885 & 790 & 1,259 & 1,457 & 2,464 & 3,474 & 3,011 & 4,854 & -10 & 1,112 & -206 & $-1,184$ \\
\hline & 2012 & 2,776 & 6,093 & 15,260 & 4,755 & $-1,503$ & $-1,361$ & 283 & 7,026 & 951 & $-1,336$ & $-1,484$ & $-1,604$ \\
\hline & 2013 & $-1,595$ & 8,759 & 14,387 & 5,866 & -371 & -830 & -789 & 2,064 & 1,311 & 864 & -495 & -423 \\
\hline & 2014 & -957 & 5,745 & 7,483 & 1,788 & 454 & -948 & $-1,396$ & 2,601 & 5,683 & -266 & $-1,568$ & $-1,633$ \\
\hline & 2015 & $-1,317$ & 5,409 & 6,628 & 4,061 & 13 & $-1,647$ & $-1,647$ & 2,898 & 4,629 & $-1,495$ & $-1,651$ & $-1,495$ \\
\hline 6. & Mukomuko & & & & & & & & & & & & \\
\hline & 2010 & -425 & -452 & 1,116 & $-1,015$ & -867 & -63 & 441 & 2,298 & 34 & -395 & 1,822 & 1,328 \\
\hline & 2011 & $-1,283$ & -130 & 1,293 & 4,365 & 731 & 888 & 106 & -630 & 1,490 & 2,253 & 6,027 & $-1,246$ \\
\hline & 2012 & -791 & $-1,145$ & -1.086 & 77 & 3,916 & -921 & 2,867 & $-1,198$ & 334 & -578 & 5,224 & 1,167 \\
\hline & 2013 & 1,122 & -664 & 238 & 3,330 & 7,135 & 4,332 & 3,422 & -940 & 2,979 & 3,434 & -926 & -637 \\
\hline & 2014 & -483 & 2,177 & 3,444 & $-1,223$ & $-1,535$ & $-1,538$ & 656 & 2,545 & 7,233 & 1,489 & -8 & $-1,001$ \\
\hline & 2015 & $-1,388$ & -529 & 4,269 & 3,173 & 3,300 & -121 & 1,264 & 361 & 13,619 & 934 & 2,637 & 486 \\
\hline 7. & Lebong & & & & & & & & & & & & \\
\hline & 2010 & -648 & -226 & 306 & 10 & 1,379 & 955 & 3,374 & 4,310 & -69 & 1,994 & 1,825 & 5,316 \\
\hline & 2011 & -569 & -392 & -99 & 3,684 & 582 & 11,826 & 4,350 & -957 & -870 & -851 & -551 & -791 \\
\hline & 2012 & 514 & 286 & -525 & -742 & 298 & 6,919 & 7,857 & 5,255 & -599 & -638 & -265 & -269 \\
\hline & 2013 & -166 & -587 & -515 & -780 & 4,583 & 8,995 & 6,996 & 937 & -854 & -459 & -618 & -614 \\
\hline & 2014 & -792 & -892 & -733 & -81 & 1,206 & 13,918 & 5,468 & -522 & -357 & -106 & -870 & -960 \\
\hline & 2015 & -966 & -958 & -422 & 2,506 & 10,634 & 11,491 & 47 & -823 & -793 & -881 & -934 & -974 \\
\hline 8. & Kepahiang & & & & & & & & & & & & \\
\hline & 2010 & -656 & -540 & 972 & 519 & -953 & 519 & 141 & 214 & 940 & 655 & 1,174 & 899 \\
\hline & 2011 & -371 & 391 & 1,306 & 422 & 1,881 & 937 & 611 & 26 & 964 & 716 & 1,685 & 636 \\
\hline & 2012 & 1,368 & 59 & 2,365 & 929 & 685 & 1,470 & 351 & 991 & 530 & 1,938 & 909 & 2217 \\
\hline & 2013 & 826 & 2,484 & 2,886 & 1,463 & 1,090 & 1,676 & 556 & 816 & 1,990 & 470 & 1,980 & 857 \\
\hline & 2014 & 1,345 & 1,564 & 3,428 & 845 & 1,005 & 1,408 & 897 & 308 & 1,565 & 3,267 & 537 & -39 \\
\hline & 2015 & -44 & -83 & 138 & -34 & 536 & 580 & 1,028 & 2,577 & 2,024 & 1,678 & 2,552 & 2382 \\
\hline 9. & Central Bengkulu & & & & & & & & & & & & \\
\hline & 2010 & 878 & 974 & 1,443 & 1,443 & 1,082 & 1,068 & 1,104 & 909 & 995 & 439 & 703 & 90 \\
\hline & 2011 & 389 & 1,692 & 1,118 & 2,498 & 492 & 10 & 1,642 & 32 & 103 & 93 & 285 & -276 \\
\hline & 2012 & -501 & 426 & 2,192 & 1,425 & 3,466 & 1,377 & 622 & -119 & 237 & 232 & 1,469 & -32 \\
\hline & 2013 & 3 & -521 & 2,631 & 3,552 & 170 & -163 & 696 & 1,175 & 1,022 & 306 & -420 & 649 \\
\hline & 2014 & 1,399 & 587 & 3,588 & 2,486 & -75 & 1,297 & -121 & -327 & 129 & -553 & 302 & -47 \\
\hline & 2015 & 242 & -237 & 2,554 & 1,713 & 755 & -186 & -501 & -306 & 1,986 & -707 & 1,671 & -328 \\
\hline 10. & Bengkulu City & & & & & & & & & & & & \\
\hline & 2010 & $-3,060$ & $-3,084$ & $-2,137$ & $-1,513$ & $-2,644$ & $-2,816$ & $-2,883$ & $-3,051$ & $-1,537$ & $-2,388$ & $-3,116$ & -2878 \\
\hline & 2011 & $-1,919$ & $-2,277$ & $-2,192$ & $-2,499$ & $-2,965$ & $-2,962$ & $-2,963$ & $-1,869$ & $-2,111$ & $-2,424$ & $-2,933$ & -3033 \\
\hline & 2012 & $-2,890$ & $-2,896$ & -233 & $-1,951$ & $-1,636$ & $-2,823$ & $-2,884$ & $-2,208$ & $-2,101$ & $-2,760$ & $-2,891$ & -2933 \\
\hline & 2013 & $-2,966$ & $-2,938$ & 353 & 322 & $-2,478$ & $-2,886$ & $-3,003$ & $-3,009$ & $-2,627$ & -695 & $-2,374$ & -2971 \\
\hline & 2014 & $-2,708$ & $-2,701$ & -345 & $-1,923$ & $-2,987$ & $-3,051$ & $-3,057$ & $-2,927$ & -840 & $-2,208$ & $-2,645$ & -3085 \\
\hline & 2015 & $-3,105$ & $-3,024$ & $-2,218$ & $-1,032$ & $-3,093$ & $-3,104$ & $-3,133$ & $-3,098$ & $-2,498$ & $-3,096$ & $-3,146$ & -3173 \\
\hline
\end{tabular}

Indeed, BULOG managed to eliminate the rice deficit which occurred in December 2012 and January 2015 and reduce the degree of deficit of rice in December 2014 which was originally severe turned into a crisis by releasing the stock of rice. However, BULOG mistakenly increased the stock of rice, so that in May 2010, month of rice deficit occurred, although it was still in the healthy category, then it aggravated the degree of deficit that 
occurred in January of 2011 , which originally was in a healthy category turned into a crisis category, and in December 2013 from the category of crisis turned into a severe category.

The monthly rice sufficiency in the regencies/municipalities can be a guideline for $B U L O G$ in making a purchase and distributing the rice stock. The monthly sufficiency of rice of Bengkulu Province in the regencies/municipalities are presented in Table 9.

The data in Table 9 show that the city of Bengkulu always experiences a deficit of rice with severe category (red). The regency which experiences most deficits is Lebong Regency. Therefore, the issue of rice insufficiency for the population of Bengkulu and Lebong Regency really need to be heeded by BULOG compared to other regions. BULOG can purchase rice in surplus areas, such as Rejang Lebong, Bengkulu Utara, Kepahiang and Central Bengkulu. The right time to make a purchase is in March, April, May, and September. Whereas the time to be on alert and to release the rice stock is January, June and December.

\section{CONCLUSION}

Bengkulu Province is in surplus of rice. The domestic rice production and the changes in the stock of BULOG of Regional Division of Bengkulu can meet the needs of the rice consumption of the people of Bengkulu. All of the regencies in Bengkulu are in surplus of rice except Bengkulu City that is in deficit condition with the category of severe (red). The monthly rice supply is unstable, consequently in January, July, and December rice deficit occurs. The deficit in rice in Bengkulu Province most frequently occurs in December.

The role of BULOG Regional Division in Bengkulu does not have much effect on the sufficiency of rice in Bengkulu.

\section{IMPLICATION}

BULOG Regional Division in Bengkulu should buy rice in Rejang Lebong Regency, North Bengkulu, Kepahiang, and Central Bengkulu, in March, April, May, and September. $B U L O G$ should be on the alert for distributing the stock of rice in the City of Bengkulu and Rejang Lebong Regency in January, June and December.

\section{REFERENCES}

1. Anriany, D., and Martianto, D. 2013. Estimasi Sisa Nasi Konsumen di Beberapa Jenis Rumah Makan di Kota Bogor. Jurnal Gizi dan Pangan. 8(1):33-38.

2. BPS-Statistics of Bengkulu Province. 2016. Bengkulu Province in Figures. BPS-Statistics of Bengkulu Province. Bengkulu.

3. Cahyani, G. I. 2008. Analisis Faktor Sosial Ekonomi Keluarga Terhadap Keanekaragaman Konsumsi Pangan Berbasis Agribisnis Di Kabupaten Banyumas. Thesis. Program Magister Agribisnis. Program Pascasarjana Universitas Diponegoro Semarang. (Tidak dipublikasikan).

4. Chai, A. and Moneta, A. 2010. Retrospectives Engel curves. Journal of Economic Perspectives. 24(1): 225-240.

5. Efrita, E. 2001. Proyeksi Kebutuhan Beras dan Minyak Goreng di Provinsi Bengkulu dan Starategi Pengadaannya. Muhammadiyah University of Bengkulu.

6. Erwidodo and Pribadi, N. 2003. Permintaan dan produksi beras nasional: surplus atau defisit?. In Ekonomi Padi dan Beras Indonesia. Badan Penelitian dan Pengembangan Pertanian. Departemen Pertanian. Jakarta.

7. Food Security Agency of Bengkulu Province. 2015. Food Balance Sheet of Bengkulu Province 2015. Badan Ketahanan Pangan Provinsi Bengkulu. Bengkulu.

8. Food Security Agency of Bengkulu Province. 2016. Dietary Pattern of Bengkulu Province, 2015. Consuption and Food Security Division. Food Security Agency of Bengkulu Province. Bengkulu. 
9. Food Security Council. 2015. A Food Security and Vulnerability Atlas of Indonesia. Dewan Ketahanan Pangan, Kementerian Pertanian and World Food Programme. Jakarta.

10. Hu, F. B. 2002. Dietary pattern analysis: a new direction in nutritional epidemiology. Current Opinion in Lipidology. 13(1):3-9

11. Lantarsih, R., Widodo, S., Darwanto, D. H., Lestari, S. B., dan Paramita, S. 2011. Sistem ketahanan pangan nasional : kontribusi ketersediaan dan konsumsi energi serta optimalisasi distribusi beras. Jurnal Analisis Kebijakan Pertanian. 9(1): 35-51.

12. Maxwell, D., Levin, C., Armar-Klemesu, M., Ruel, M., Morris, C., and Ahiadeke, C. 2000. Urban Livelihoods and Food and Nutrition Securuty in Greater Accra, Ghana. International Food Policy Research Institute in Collaboration withNoguchi Memorial Institute for Medical Research andWorld Health Organization. Research Report No. 112. Washington D. C

13. Nur, Y. H., Nuryati, Y., Resnia, R., and Santoso, A. S. 2012. Analisis Faktor dan Proyeksi Konsumsi Pangan Nasional: kasus pada komoditas beras, kedelai dan daging sapi. Litbang Perdagangan 6(1):31-52.

14. Park, S.Y., Murphy, S. P., Wilkens, L. R., Yamamoto, J.F., Sharma, S., Hankin, J.H., Henderson, B.E., and Kolonel, L.N. 2005. Dietary patterns using the food guide pyramid groups are associated with sociodemographic and lifestyle factors: the multiethnic cohort study. The Journal of Nutrition. 135:843-849.

15. Romdhon, M. 2013. Optimalisasi Lahan Sawah untuk Memenuhi Target Pendapatan Petani Setara Pendapatan Perkebunan di Provinsi Bengkulu: Pendekatan Stochastic Profit Frontier dan Goal Programming. Dissertation of Program Studi Doktor IImu-IImu Pertanian the Faculty of Agriculture, Sriwijaya University. Pelembang.

16. Sjarkowi, F. 2015. Kedaulatan Pangan, Siasat Agribisnis Pangan Kebangsaan Penguat Keutuhan NKRI. Badan Kajian dan Penerbitan ICMI Sumatera Selatan. Palembang. 